\title{
Stimulation of Conflict in the Contemporary Indian English Campus Novels
}

\author{
Ms. Sneha Kanaiyalal Patel \\ Research Scholar, School of Liberal Studies, Pandit Deendayal Pertroleum University, Raisan, \\ Gandhinagar, Gujarat
}

\begin{abstract}
Contemporary Indian English campus novels are a pleasant source of information for the neo readers and a flashback of delightful journey of college life for the experienced people. The relationships which are presented in them are undoubtedly cordial, friendly and loving. Amidst the saga of love and friendship, conflicts do arise among the triumvirs of contemporary Indian English campus novels, viz. students, teachers and parents. Conflicts give rise to adverse situations but the characters who deal with them ultimately commence victorious after accepting and dealing efficiently with the challenges head on. The present paper focuses on the conflicts that the characters face in the contemporary Indian English campus novels.
\end{abstract}

Keywords: Contemporary Indian English campus novels, conflicts, students, teachers, parents

\section{INTRODUCTION}

Contemporary Indian English campus novels provide focus on varied dimensions of emotions that the characters undergo in different situations. They often find themselves in a state of serious incompatibility, struggle or clash and being at variance with other characters or with the prominent educational system. There are significant factors that elevate the conflicting instinct among the prominent characters of the contemporary Indian English campus novels.

\section{- Ragging}

Ragging is a brutal form of entertainment which is obtained at the cost of humiliation, shame and injured self esteem of others. Though ragging is against the law, some of the seniors do not refrain from enjoying their share of entertainment. Every fresher dreads undergoing this humiliating treatment. In the contemporary Indian English campus novels under study, ragging is mostly done in the students' hostel especially during the night time.

In Five Point Someone, Chetan Bhagat describes the ragging scene with a tinge of humour. Hari, Ryan and Alok are at the scrutiny of their seniors whom they address as 'sir'.

As per tradition, seniors rounded us up on the balcony for ragging at midnight. I was still rubbing my eyes as the three of us stood to attention and three seniors faced us. A senior named Anurag leaned against a wall. Another senior, to my nervous eye, looked like a demon from cheap mythological TV shows - six feet tall, over a hundred kilos, dark, hairy, and huge teeth that were ten years late meeting an orthodontist. Although he inspired terror, he spoke little and was busy providing background for the boss, Baku, a lungi-clad human toothpick, and just as smelly is my guess. (2)

Unable to tolerate this ordeal, Ryan finally takes charge of the situation and rages his voice out at the seniors who though flabbergasted, leave the freshers alone thus saving them from experiencing further agony.

Anirban Bose in Bombay Rains, Bombay Girls gives an apt description of ragging.

Ragging marks the unofficial beginning of many a distinguished career in medicine. Rivaling an ancient Roman sport in its viciousness, the stories from this cold, brutal tradition get repeated like an old maid's tales amongst the incoming group of 'freshies'. They curse the custom with helpless rage, only to turn into its major proponents the following year, when an infusion of fresh faces unfailingly entices them into this orgiastic revelry. And so the hideous heritage thrives, carried on by the victim-turned aggressors baying for their share of fresh blood. $(23,24)$ 
Ragging is fun-spirited in Everything You Desire, which is aimed to welcome the freshers in a jovial manner. The protagonist Harsh shares his experience of ragging.

I wondered what was the need for all this elaborate arrangements for a group photo. After feeding on a few oily samosas and a cup of tea, Deepak and I went to the Tsepak court. A number of people were there. The girls looked good in colourful sarees. In few minutes, the whole batch was there. Some seniors were also hanging around. The Presi was giving instructions to someone and before anyone knew anything it started raining-not the natural one, but buckets of water non-stop. More seniors appeared as we all rushed to move out of the court. The seniors, hiding on the terrace began shouting "Welcome to IIMB!" We all were thoroughly drenched. "Ok everyone. This is the traditional IIM welcome. Great to have you in the IIMB community" announced Dabaas. There was a round of applause as we could just laugh at ourselves- we really had been fooled, but it was all in good fun! (17)

\section{- Campus Politics}

Campus politics form an integral part of the contemporary Indian English campus novels. Students fight out for various positions ranging from class representative (CR) to general secretary (GS) along with the other significant posts like cultural secretary, hostel secretary, alumni secretary, placement secretary and so on.

In Love, A Rather Bad Idea, the protagonist, Samar gets quite obsessed about winning the G-Sec election. Samar's obsession for winning the G-Sec election against his best friend Pranav became so severe that he didn't mind harming Pranav with the help of Yadav and Tejbhai. Eventually, Samar comes to his senses and during the last phase of the election campaign, he gives up his candidature. His political ambition alienates him from his friends and lady love who he wins over finally.

In Bombay Rains, Bombay Girls, Anirban Bose brings forth the racial issue that surface during the CR elections. This emerges in the outburst of Sam.

Sam suddenly snorted with anger. 'Minorityism? Is that what you call it, Rajeev?' he shouted. 'Hmm, let's see...Do you know why I lost the first election for the Class Representative's post? Huh? Do you ...? I lost it because Manish and his gang spread the word about how I wasn't a true Maharashtrian. I was born and brought up in Pune. I learnt Marathi in school and can speak and write better Marathi than all of you. I burst crackers with the friends in my neighbourhood during Diwali, and they'd come over to our house to have cake at Easter. And yet, when the time comes to choose, I am not Maharashtrian?' (425)

Harshdeep Jolly writes about how the nominees do their best to woo the votes from their classmates in Everything You Desire.

Different people love different challenges. Some prefer to claim superiority in the academic battle while others try to make their mark in the electoral battlefield. You get opportunities for both on campus. The first challenge was due in a week's time-the mid semester exams-the first for us at IIMB. The week after that was the week for the PGP1 elections. Each section was going to elect its respective class representative. In addition there were posts of junior sports secretary, junior cultural secretary and junior alumni secretary up for grabs. While exams were important for all, the "politicians" were more inclined to spend prospecting for votes. Examinations in fact helped them in a wayhelping people get some regular guy's notes, getting some old papers from seniors and putting it in the photocopy shop and so on. Where there is a will, there is way to woo the electorate! (56)

Winning any post is not just a matter of satisfying one's power motive but it also boasts up one's resume. Vinay advises Harsh to contest for any of the post in election.

But, don't you realize that if you hold a post of responsibility, it is a good achievement. You are so interested in going into consulting. You should try to get one of these posts. All the consults look for such leadership traits. (127) 
The nominated students behave as real politicians when they ask for votes. They appeal to others to vote for them in a very humble and friendly manner.

The three candidates for Class Representative Post from our section were busy mingling with the "voters".

Rohit was busy wooing Partho and Avinash. "DMLs ho yaar tum to, crack kar diye hoge midterms! You guys are really brilliant. I admire you. Waise I hope I can count on your support for CR elections," he was saying in his humblest tone.

"Crappy guy, better vote for Thakur. Atleast the guy knows how to speak and is presentable," opined Dipendu.

Thakur was busy wooing the girls-he didn't need to do that though! Most people felt the "girl vote" is for his taking anyways!

“Kanhaiya kahin ka!” said Tushar disparagingly.

I laughed as Rohit came towards us.

"Sirjee, how did the exams go? You must have cracked them," he said to me.

"You would be looking to top I think." He said turning his face towards Tushar.

"Thanks and you would be looking to top the elections now," I said.

"With blessing from you guys, I hope I can do something yaar," he said with a smiling face in typical politician style, which I found irritating. $(59,60)$

\section{- Feeling of Jealousy}

The feeling of pride automatically seeps in when one gets admission in a college of repute and marked distinction. When Samar, in Love, A Rather Bad Idea, gets admission in IIT, his parents are overjoyed but his friends Kittu and Inder, who were once cordial and friendly, react differently and in an unfriendly manner when Samar goes to meet them.

Come, show us what IIT teaches you. Let's see if the IIT chap can beat the Chandigarh de badshahs in bowling. ..."Couldn't be better guru," Kittu gave a wide smile to Samar. 'I am managing the entire north operations of dad's computer business. You won't believe the kind of scale I am managing nowadays. I am even thinking of branching out into gaming. Let's see. Maybe I will employ a few IITians to run my show, huh? $(173,174)$

\section{- Confusion in Relationships}

Human relationships at times become quite confusing and complicated especially in the matter of love when one does not realize what one really wants.

Abbey, in Mediocre But Arrogant, gets confused because of his mixed feelings towards two girls at the same time.

Two terms in MIJ did strange thing to me. I found myself becoming very competitive, as far as getting Ayesha's attention was concerned. My correspondence with Priya also began to get more and more infrequent. (167)

Abbey is not able to be decisive about his feeling as even towards the end of the novel his confusion prevails.

Durjoy Dutta and Maanvi Ahuja reveal the confused state of the protagonist Deb in the title of the novel itself, which reads as 'Of Course, I Love You..! Till I Find Someone Better.... Deb doesn't want to commit to anybody and seeks temporary relationships.

After all it is easier to love a busy, open to everything, smart girl rather than loving somebody you love. (12)

Deb only wants to involve in casual relationship with girls. As he says,

People around me wanted love, care and long conversations for whatever that meant. I just had to find somebody to love. Or at least somebody I would not hate after the first few weeks. (2) 
In Love, A Rather Bad Idea, Jiya is Skimpy's girlfriend in the beginning of the novel but when it ends she becomes the love interest of the protagonist Samar. Tushar, in Everything You Desire, already has a girlfriend named Sarika before he enters IIM. Then he gets attracted towards Priya who in turn is Sarika's friend. Tushar breaks up with Sarika and tries to woo Priya. Consequently, Priya too starts taking interest in Tuhar. Thus, the contemporary Indian English campus novels under study even display love relationships which are fragile, fake and fickle.

\section{- Students versus Teachers}

Teachers and students are the eminent factors of the teaching-learning process. Gone are the utopian days when students obediently followed the command of their teachers willingly or unwillingly. Nowadays, students are techno savvy and well informed. The education system has become student oriented. Students often question the authority of their teachers. There is no general disrespect for the teachers but they are perceived as humans with flaws. Ryan's outburst in Five Point Someone justifies this.

And this IIT system is nothing but a mice race. It is not a rat race, mind you, as rats sound somewhat shrewd and clever. So, it is not about that. It is mindlessly running a race for four years, in every class, every assignment and every test. It is a race where Profs judge you every ten steps, with a GPA stamped on you every semester. Profs who have no idea what science and learning are about. Yes, that is what I think of the Profs. (101)

Prof Bhanumati Sahu, in Sumthing of a Mocktale, fails to engage her students in the very first lecture and this continues till the course ends. Kaya speaks about her performance in the class.

In her first class she embarked on a green journey. "I don't know but I think all of you should have heard about Green Revolution. Well the basic contributor to this revolution was HIV seeds." We didn't know whether we heard it right but she continued unperturbed, unfettered "HIV seeds once shown on fertile land can do wonders. HIV seeds can multiply the product many times as has happened in India during 1960s...And Ragini murmured next to me "Oh God! Is she actually talking about HYV, High Yielding Variety Seeds?" ...Can you point out another demerit?

"Yes Ma'am, it can cause AIDS" I don't think the insignificant voice listened to the lecture at all. Quite early in the semester, we had given up on Bhanu and Bhanu had given up on us. (13)

Adi in Bombay Rains, Bombay Girls is an animal lover and voices out his thoughts against killing of a frog during an experiment. Dr. D'Souza misunderstands him initially and scolds him.

Dr. D’Souza stopped mid-sentence. His eyes, brimming with rage, froze on Adi. 'I heard that! How dare you! How dare you say that!' ...Adi shrugged. 'I just think it is cruel to kill the frog, Dr. D'Souza. This experiment has been done hundreds of times and I can't understand why we have to torture the poor frog...Everybody froze, staring at Adi with disbelief. In the overbearingly paternalistic education system, Adi had violated the sacred hierarchy of the teacher-student relationship-a hierarchy usually etched in stone. The onlookers waited with bated breath for the hammer to come down. Only the frog continued to breathe rapidly in the small jar. $(143,144)$

Following Adi, entire class requests Dr. D'Souza not to kill the frog and offers various ways of learning the experiment. Dr. D'Souza gives into the general plea of his students.

In Everything You Desire, students are under persistent scrutiny and threat of Prof Shanker and Prof Ranganathan. Harsh writes about the mental condition of the students who give their presentations in front of their teachers.

More than grades, they were worried about Professor Shanker's public humiliation treatment, of which we had now seen enough examples. (70)

In Second Degree, Uncle (a senior student who is also married), voices out his difference of opinion which is not taken favourably by the teacher, who is nicknamed Professor Lady Herminator, and has to face her fury.

"Ma'am with all due respect, I don't understand anything in the paper you told us to read for class today." Uncle spluttered bravely. 
"How dare you?" The Professor screamed "Something must be wrong with your head! This paper has been well received all across the world by several dignitaries and distinguished scholars!"

...Uncle wondered how many of the dignitaries and distinguished scholars the coterie had heard about, but he was too ticked off to say anything more.

The news of this confrontation spread like wildfire. Soon a vast majority of the class just stopped reading up anything in the subject. (141)

In the novel, Anything for You Ma'am, in order to meet his lady love Shreya, in Chennai, Tejas lies to Prof. P.P. Sidhu, popularly known as Pappi, about his family problems and his inability to be a part of the educational tour. The relationship between the two is really strained in the course of the novel. It's just towards the end of the novel; Tejas is relieved and finds an aid in Prof P.P. Sidhu.

\section{- Students versus Parents}

It is a general perception that parents want to provide everything best to their children. Authors of Joker in the Pack, Ritesh Sharma and Neeraj Pahlajani, reiterates this attitude of the parents in their novel through the protagonist Shekhar. This view is rather sarcastic.

Like other middle class families around them, they were a content and hard-working twosome living with their extended family. In 1984, two years after their marriage, they were blessed with a baby boy. When the baby was born, Ashok and Vasudha had made a silent pledge within their hearts to leave no stone unturned in pampering him with all that they never got during their own lives. 'All that they never got' was not an idyllic garden laden with cookies and cream pies. 'All they never got' was good schooling in an English medium institution, tuitions to supplement the schooling, and a circle of friends that was focused on education and careers. That was it. From where they saw the world, those were the most precious assets a child could get early on in his life. And it seemed the entire middle class society of their times was well-aligned with this ideology. (12)

Samar in Love, A Rather Bad Idea, goes to Chandigarh, his hometown, after a long time and is relieved to believe home as a place where he would be understood and heard, no matter what. His parents are busy socializing with their relatives and want Samar to partake in the same. Samar realizes that he could not escape the difficulties he faces in his college and with his friends and thus decides to go back to IIT Delhi, and face his problems head on.

Shreya's parents disapprove their daughter's romantic relationship with Tejas in Anything for You Ma'am. Her father is dejected when he reads the love letter that Tejas writes for Shreya.

Her mom played a passing-the-parcel, and gave the letter to her dad and any dad, on discovering a letter written by a lover to his daughter addressing her dangerous things like darling and sweetheart, leaps in the air and so did Mr. Bhargava, her father, and in that process hit the ceiling impairing his brain forever. I don't blame him. It is perhaps natural for I have seen documentaries that study a dad's reaction on the discovery of his daughter's darling and they all show the same thing. The dad goes mad. For him it is not merely a letter, but a time bomb, ticking away, threatening to blow his daughter away one day. And when a dad goes mad, he decides that his daughter must be kept in strictest of custodies, with barbed wires and all. (8)

Difference of attitude towards gender is depicted in Vernita's account of the parents of Avantika and Tanmay in Of Course, I Love You...!

She wanted to take up engineering but her parents wanted something else for her. They wanted her to get married, as soon as possible. She had fought her way through the years after she turned eighteen. Through rough relationships, hostile parents, Drugs and alcohol. Her parents knew nothing about it. They had gotten used to the snubbing and vice versa. It was strange to see how little they cared about her. They know everything about Tanmay and what he was up to but shockingly they had no idea about Avantika's Drug problem.

Abbey's father in Mediocre But Arrogant wants his son to know about the way to excel in life. His idea is not well appreciated by Abbey. 
'If you do not feel comfortable and relaxed, you will learn to be a fighter. Luxury will dull your desire to excel.' This was what my father said every time I desired but was denied something that was even remotely classified as a luxury. (5)

Skimpy's mother in Love, A Rather Bad Idea is over ambitious, authoritative and wants to shape up her son's career according to her whims. The protagonist Samar gives an account of her personality.

Skimpy's mother was like a fast-moving, overly ambitious guardian who could not accept anything but the best for her son. The moment she would enter a room, she would inevitably take complete charge of it. She would fire a few orders, pivot the conversation to thing she had an interest in, and make everyone around her feel obliged to please her. One could see Skimpy practically wilting in her presence. His eagerness to come up to par on her evaluation scale was matched only by his complete inability to do so. ...Skimpy's mom lived in a make-believe world of her own where her son was as magnetic and achievement-oriented as her. $(177,178)$

Prof Cherian opposes Neha's link up with his student Hari in Five Point Someone. Even Hari, Ryan and Alok are not in complimentary terms with their parents. Alok desired to become a painter as he was really good at painting. However, owing to his father's illness and poor financial condition of his family, he studies hard and gets admission in IIT in hope of a brilliant career that would save him from all the financial problems. In the chapter titled, 'Ryan Speaks', we realize the problems of Hari. Hari's father being a colonel in the army is very strict and disciplined. He punishes Hari severely while questioning him about his wrong doings. Whenever Hari faces the viva, he becomes nervous and fails to express himself. This nervous behaviour of Hari is attributed by Ryan to his parents' way of upbringing Hari.

And your mother -she turns silent for days, right? Oh, wait a minute, I am not supposed to talk about that. What about the belt your father hangs in the closet. Do you still Dream of that sometimes, Hari? He told you not to answer back. If you answer your superiors back, you will be punished. Severely. Is it viva-time? Does it still hurt, Hari? (218)

Ryan's parents are rich and provides him with ample of money but they do not have any time or interest to keep a check on his career and life at college.

Conflict between Prof Cherian and his son Samir turns out to be fatal for Samir. In his letter to his sister, Samir confesses about his being tired to prove his caliber to his father and ultimately decides to commit suicide.

I have tried three times to get into IIT, and each time I have disappointed Dad. He cannot get over the fact that his son cannot handle physics, chemistry and maths... He has not spoken to me for two months. He doesn't even talk to mom properly because of me. What can I do? Keep trying until I die? Or simply die? $(168,169)$

Consequently, the tension and conflict which the students face from their parents and vice versa have a lasting effect on each other's perceptions of love, friends, career and life.

\section{- Students versus Students}

To make a mark by establishing a victorious position for themselves, students often challenge one another. This conflict among the students is quite evident among Rohit, Thakur and Pradeep in Everything You Desire when they contest against one another in the CR elections.

In Second Degree, Prashant John enrolls for an MBA course, at the age of 28, after leaving his job. He and his friends Varun, Subbu and Sweety don't feel at ease and comfort while interacting with the students having no professional experience backing them.

Soma Das, in Sumthing of a Mocktale talks about the girls who come to study in JNU from West Bengal. They remain in their clan and view others as competitors.

CSODR Bongs are hundred percent Homosapiens but a different sub species within it. Of the total 16 girls, 9 were Maa Go club members, so you can well imagine the plight of the rest. The mini-Bengal dominated mini-Inida by virtue of numerical majority but I suspect they would reign over even if they hadn't had numbers on their side. Rumpa, Jhumpa, Tumpa, Shampa,...the Pa dynasty we hear had invaded CSODR shortly after its inception and has been ruling supreme since generations. (17) 
In Bombay Rains, Bombay Girls, Sam talks about his and Toshi's plight as compared to other students. Sam was kept at bay from winning the election as he was a Christian and Toshi was viewed differently as he hailed from the north-east India, Nagaland. Religion and region instigate conflict among students as Sam makes his point.

The worst part of it was that Manish's ploy worked. I couldn't believe that educated people, on their way to become doctors some day, would vote with such narrow minds and believe I'm not Maharashtrian because I'm not Hindu. And I'm narrow -minded? That day, I lost faith in people's judgement. And do you know who understood? Toshi. Do you know why? Because he could feel the hurt! Not the hurt of losing the election, but the hurt of being different... of not being accepted... of not being "one-of-us". $(425,426)$

\section{CONCLUSION}

By facing and coping with the situations which seem adverse, the characters realize their potential and their own self. They come to terms with realities of life and learn to challenge the situation or let it pass as it is. Conflicts do help in building up confidence in the characters and enable them to take charge of the situation. Their understanding develops and they learn to tackle things in their own stride. College campus is a kind of miniature society and thus characters not only deal with the issues which are related to education but they also come across the social and cultural issues. The situations are dealt either with struggle or humorously. In either case, these conflicts imbibe better understanding, judgment and evaluating potentiality among the characters of the contemporary Indian English campus novels.

\section{REFERENCES}

Merriam, Webster. Merriam-Webster's Collegiate Dictionary, 11th Edition, Merriam- Webster, Inc., 2003.

Bhagat, Chetan. Five Point Someone. New Delhi: Rupa Paparback, 2004.

Bhaduri, Abhijit. Mediocre But Arrogant. New Delhi: HarperCollins Publishers India, 2005.

Raheja, Tushar. Anything for You Ma'am. New Delhi: Shristi Publishers and Distributors, 2006.

Das, Soma. Sumthing of a Mocktale. New Delhi: Shristi Publishers and Distributors, 2007.

Jolly, Harshdee Everything You Desire. New Delhi: Shristi Publishers and Distributors, 2007.

Sharma Ritesh, and Pahlajani, Neeraj. Joker in the Pack. New Delhi: Orient Paperbacks, 2007.

Datta, Durjoy, and Ahuja, Maanvi. Of Course I Love You..!. New Delhi: Shristi Publishers and Distributors, 2008.

Bose, Anirban. Bombay Rains Bombay Girls. New Delhi: HarperCollins Publishers India, 2008.

John, Prashant. Second Degree. Ahmedabad: Eklavya Education Foundation, 2009.

Mukherjee, Anirban. Love, A Rather Bad Idea. New Delhi: Shristi Publishers and Distributors, 2010.

AUTHOR's BIOGRAPHY

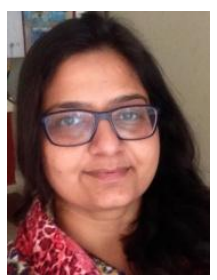

Name: Sneha Kanaiyalal Patel

DOB: $14 / 11 / 1976$

Qualification: MA (Eng Lit), M.Ed.

- Pursuing PhD (Eng Lit) from PDPU

-working as an asst teacher in M B Patel English Medium School, SVKM in the higher secondary section

-writer and reviewer in Gujarat state board of textbooks

-subject expert for e-development of English first language STD. 9-12 textbooks in Gujarat Secondary and Higher Secondary Education Board 